\section{Gut Microbiota Dysbiosis and Role of Probiotics in Infant Colic}

\section{Abstract}

Infant colic or excessive crying syndrome is a behavioral syndrome in 1- to 5-month-old infants involving long periods of inconsolable crying and fussing in otherwise healthy infants. Its etiology is unclear, but evidence regarding the implications of the infant gut microbiota is rising in importance.

In this short review, we aim to expose recent findings on alterations in the microbiota of colicky infants which could trigger or facilitate infant colic, and summarize the clinical and mechanistical evidence of several probiotic formulations for the management of infant colic.

The observed increase in the relative abundance of Enterobacteria in colicky babies may facilitate intestinal hypersensitivity due to their endotoxins, while also increasing the amount of intestinal gas, and thus, bloating and digestive discomfort. Also, an association between infant colic and a decrease in the relative abundance of protective bacterial groups such as bifidobacteria or lactobacilli has been pointed out by independent research groups. Therefore, it is not surprising that many clinical trials have explored the effects of supplementing the microbiota of colicky infants with probiotics due to their known effect in modulating gastrointestinal microbiota.
Tintore $\mathrm{M}^{1 *}$, Colome $\mathbf{G}^{2}$, Santas $\mathrm{J}^{1}$ and Espadaler $\mathrm{J}^{1}$

\author{
1 AB-Biotics, S.A., ESADE Creapolis, 08172, \\ Sant Cugat del Vallès, Barcelona, Spain \\ 2 Children's Gastroenterology Unit, \\ Barcelona Children's Hospital \\ Foundation, 08009 Barcelona, Spain
}

*Corresponding author: Tintore M

tintore@ab-biotics.com

AB-Biotics, S.A., ESADE Creapolis, 08172, Sant Cugat del Vallès, Barcelona, Spain.

Tel: +34686445797

Citation: Tintore M, Colome G, Santas J, Espadaler J (2017) Gut Microbiota Dysbiosis and Role of Probiotics in Infant Colic. Arch Clin Microbiol. Vol. 8 No. 4:56

Received: July 25, 2017; Accepted: August 04, 2017; Published: August 10, 2017

\section{Introduction}

Infant colic or excessive crying syndrome is a behavioral syndrome in 1- to 5-month-old infants involving long periods of crying and hard-to-soothe behavior. The crying bouts occur without obvious cause, so that their unexplained nature is one of the main reasons for caregivers' concerns [1]. Its etiology is unknown and possibly multifactorial [2]. Because it affects otherwise healthy infants without a specific cause, infant colic has a controverted physiopathology. In addition, it represents an auto-limited syndrome that disappears after the fourth or fifth month of life. For all these reasons, infant colic is classified as a Functional Gastrointestinal Disease (FGID) [1]. The incidence of infant colic has been reported to range from $8 \%$ to $20 \%$ [3], and represents the cause of $10-20 \%$ of all pediatrician visits in the first 4 months of life [4].

Infant colic was initially defined in 1954 by Wessel as an excess of crying or paroxystic irritability without an apparent cause, for more than three hours a day, occurring more than three days a week in three consecutive weeks [5]. However, different concerns were risen regarding this definition, as in daily practice a noticeable population of infants shows an abnormal and unexplained crying profile despite not perfectly fitting Wessel's criteria. Subjective assessment of crying time was also found to be dependent on the cultural environment of the patient, being subjected to a high variability. For this reason, Wessel's criteria have been abandoned and the international association for FGIDs, known as the Rome Foundation, has reached a consensus definition of colic as "Recurrent and prolonged periods of infant crying, fussing, or irritability reported by caregivers that occur without obvious cause and cannot be prevented or resolved by caregivers" [6]. This new definition is also a consequence of the high interest displayed by the pediatrician community in identifying this pathology, to investigate and provide adequate treatment.

Colicky bouts are more frequent in the late afternoon or evening, starting suddenly and being intense and often high pitched [7]. Moreover, 'colicky infants' are usually very unsettled, fussy or irritable or may show signs of pain (e.g. drawing up knees or arching the back) [8]. Colic is often a serious issue for parents, as excessive crying leads to parental exhaustion and anxiety, with negative consequences such as: difficulties to concentrate, loss 
of patience, feelings of incompetence, fear of harming the child, early cessation of breastfeeding and reduction of face-to-face interaction with their child $[8,9]$.

\section{Etiology of infant colic and role of gut microbiota}

A variety of causes for infant colic have been suggested, including abnormal gastrointestinal function, immaturity of the gut, spastic colon, accumulation of gas, allergic problems and lack of sufficient parent-to-child interaction (Table 1) $[2,6,10]$. Despite this unclear and possibly multifactorial etiology, studies by independent research groups have correlated alterations in gut microflora with infant colic [11-16]. This consideration has been growing in importance since the early observations of lower counts of intestinal lactobacilli and bifidobacteria in colicky infants compared to healthy ones $[17,18]$

As a result of the aforementioned studies, the microbiota profile of colicky infants can start to be delineated. First, omics studies conducted by different means (e.g. microarrays, metagenomic analysis) have reported a reduction in overall microbiota diversity compared to healthy infants $[12,19]$. Second, particular alterations comprising a reduction in the proportions of Bifidobacteria [20,21], Bacteroides [21] and lactobacilli [14,15,2022], and an increase of Clostridium, Staphylococcus and specially of Enterobacteria such as Escherichia, Shigella, Klebsiella or Enterobacter have been found [11-13,15-19,23].

\section{Implication of microbiota disturbances in the symptoms of infant colic}

Lower microbiota diversity and stability in the first weeks of life may lead to changes in the metabolome of gut microbiota, the ensemble of gut microbiota by-products which influence human health $[24,25]$. In turn, changes in bacterial metabolome can alter the speed of intestinal transit, facilitating an accumulation of gas causing general digestive discomfort $[11,14,26]$. Also, deregulation of motor function could result in spasmodic bowel movements, leading to pain. Additionally, a less diverse gut microbiota has been associated with higher levels of calprotectin, a known biomarker of gut inflammation [19].

As described above, relative abundance of opportunistic and commensal Enterobacterial species seem to increase in infant colic in comparison to healthy infants $[12,21]$. These bacteria are known to produce gas as a result of their metabolism [27], which could facilitate bloating and digestive discomfort in colicky babies [11]. Moreover, lipopolysaccharide (LPS) molecules (also known as endotoxins) from Enterobacteria are especially proinflammatory, compared to LPS from other common gut Gramnegative bacteria such as Bacteroides [28]. Inflammatory effect of LPS is mediated by Toll-like receptors, and is known to reduce visceral sensory and pain thresholds (allodynia) both in animal models and in humans [29-31]. By this mechanism, a higher relative abundance of Enterobacteria could facilitate a state of low-grade inflammation and increased visceral sensitivity in colicky infants.

In contrast, evidence suggests that a high proportion of Bifidobacterium and Lactobacillus in the infants microbiota is protective against colicky crying and fussing $[12,20]$. This protective effect might be related with the fact that mucosal Lactobacillus are able to induce the expression of antiinflammatory genes [32], improving gut function and motility and exerting a reduction of visceral pain [33,34]. In addition, lactobacilli and bifidobacteria may protect against colic by modulating immune response [35]. Alterations in gut microbiota of colicky infants are summarized in Table 2. Importantly, some factors related to the intestinal microbiota are age-related, which could help explain why infant colic resolves spontaneously around 4 to 6 months of age [2]: First, bile acids represent a key environmental factor modulating gut bacteria at high taxonomic levels, and overall bile acid metabolism is altered during the first months of life (as demonstrated by the fact that cholic to chenodeoxycholic acids ratio in duodenum and bile acid levels in serum are increased during the first months of life). Second, the overall diversity of the intestinal microbiome has been described to increase in an age-related manner during the first months of life, and increased diversity is known to make ecosystems more resistant to perturbations by opportunistic organisms (such as Enterobacteria in the gut).

\section{Treating infant colic with probiotics}

Since an effective solution for excessive crying is not available

Table 1 Possible factors implicated in the ethiopathology of infant colic.

\begin{tabular}{|c|c|}
\hline \multirow{8}{*}{$\begin{array}{l}\text { Factors intrinsic } \\
\text { to the infant }\end{array}$} & $\begin{array}{c}\text { Immaturity of the intestinal tract and of the } \\
\text { epithelial barrier }\end{array}$ \\
\hline & Microbial imbalance in the gut microbiota \\
\hline & $\begin{array}{l}\text { Immature gastrointestinal function (motility, bile } \\
\text { acid mechanisms) }\end{array}$ \\
\hline & Accumulation of gas \\
\hline & Spastic colon \\
\hline & Alterations in gut hormones \\
\hline & Transient food intolerance or allergy \\
\hline & $\begin{array}{c}\text { Last stage in the developmental "crying curve" of } \\
\text { healthy infants }\end{array}$ \\
\hline \multirow{6}{*}{$\begin{array}{l}\text { Factors related } \\
\text { to parents-infant } \\
\text { interaction }\end{array}$} & Insufficient parent-to-child interaction \\
\hline & Family tensions \\
\hline & Parental anxiety \\
\hline & First born status \\
\hline & Maternal smoking \\
\hline & Increasing maternal age \\
\hline
\end{tabular}

Table 2 Alterations in gut microbiota of colicky infants that may be implied in the ethiopathology of infant colic.

\begin{tabular}{|c|c|}
\hline Microbiota alteration & Implication in infant colic \\
\hline \multirow{4}{*}{$\begin{array}{l}\text { Low microbiota diversity } \\
\text { and stability: changes in } \\
\text { metabolome }[12,14,19]\end{array}$} & Alterations in intestinal transit \\
\hline & Spasmodic bowel movements \\
\hline & Gas accumulation \\
\hline & $\begin{array}{l}\text { Higher levels of calprotectin: } \\
\text { inflammation }\end{array}$ \\
\hline \multirow{2}{*}{ 个Enterobacteriaceae $[12,21]$} & $\begin{array}{c}\text { Gas accumulation: bloating and } \\
\text { digestive discomfort }\end{array}$ \\
\hline & $\begin{array}{l}\text { Pro-inflammatory and hyperalgesia } \\
\text { reaction to LPS }\end{array}$ \\
\hline$\downarrow$ Bifidobacterium $[12,52]$ & Immune response modulation \\
\hline$\downarrow$ Lactobacillus $[12,52]$ & Expression of anti-inflammatory genes \\
\hline
\end{tabular}


as of today, it represents an unmet clinical need and there is a high interest in understanding its physiopathology to provide the best available treatment. Because of the evidence of microbiota changes in colicky infants, some probiotic formulations have been studied for the management of infant colic, as summarized in Table 3. The studies have focused mainly on the reduction of crying time as a primary outcome of baby's discomfort.

In an early double-blind, randomized, placebo-controlled study

Table 3 Comparison of the different effects of probiotics on infant colic described by clinical trials. Since all studies reported good tolerability and absence of side effects, these are not included in the table. FF: Exclusively or predominantly formula-fed; BF: Exclusively or predominantly breast-fed.

\begin{tabular}{|c|c|c|c|c|c|}
\hline Probiotic & Study & Design & Population & Endpoints & Results \\
\hline $\begin{array}{l}\text { Bifidobacterium } \\
\text { lactis BB-12 + S. } \\
\text { termophilus }\end{array}$ & $\begin{array}{l}\text { Saavedra } \\
\text { et al. } 2004 \\
{[36]}\end{array}$ & $\begin{array}{l}\text { Randomized, double-blind, } \\
\text { placebo-controlled study. } \\
\text { Prophylactic intervention }\end{array}$ & $\begin{array}{l}180 \\
\mathrm{FF}\end{array}$ & $\begin{array}{l}\text { Crying and fussing } \\
\text { behavior (reported by } \\
\text { parents) }\end{array}$ & $\begin{array}{l}\text { Significantly lower reported incidence of } \\
\text { colic in the probiotic group }\end{array}$ \\
\hline \multirow{24}{*}{$\begin{array}{l}\text { Lactobacillus reuter } \\
\text { DSM } 17938\end{array}$} & \multirow{3}{*}{$\begin{array}{l}\text { Savino et } \\
\text { al. } 2010 \\
\text { [37] }\end{array}$} & \multirow{3}{*}{$\begin{array}{l}\text { Randomized, double- } \\
\text { blinded, placebo-controlled } \\
\text { study }\end{array}$} & \multirow{3}{*}{$\begin{array}{l}46 \\
B F\end{array}$} & Crying time & $\begin{array}{l}\text { Reduction in crying time in the probiotic } \\
\text { group after } 21 \text { days }\end{array}$ \\
\hline & & & & $\begin{array}{l}\text { Responders rate }(50 \% \\
\text { reduction in crying time) }\end{array}$ & Significantly higher in the $L$. reuteri group \\
\hline & & & & Gut microbiota & $\begin{array}{l}\text { Significant increase in fecal lactobacilli } \\
\text { Reduction in fecal Escherichia coli and } \\
\text { ammonia in the L. reuteri group }\end{array}$ \\
\hline & \multirow{4}{*}{$\begin{array}{c}\text { Szajewska } \\
\text { et al. } 2013 \\
\quad[38]\end{array}$} & \multirow{4}{*}{$\begin{array}{l}\text { Randomized, double- } \\
\text { blinded, placebo-controlled } \\
\text { study }\end{array}$} & \multirow{4}{*}{$\begin{array}{l}80 \\
B F\end{array}$} & $\begin{array}{l}\text { Responders rate }(50 \% \\
\text { reduction in crying time) }\end{array}$ & $\begin{array}{l}\text { Significantly higher in the probiotic group } \\
\text { on days } 7,14,21 \text { and } 28\end{array}$ \\
\hline & & & & Crying time & Significantly reduced in the probiotic group \\
\hline & & & & $\begin{array}{l}\text { Parental perception of } \\
\text { colic severity }\end{array}$ & Significant reduction already on day 7 \\
\hline & & & & Family quality of life & Significant improvement already on day 7 \\
\hline & \multirow[b]{2}{*}{$\begin{array}{l}\text { Roos et al. } \\
2013[21]\end{array}$} & \multirow{2}{*}{$\begin{array}{c}\text { Randomized, double- } \\
\text { blinded, placebo-controlled } \\
\text { study }\end{array}$} & \multirow[b]{2}{*}{$\begin{array}{l}29 \\
B F\end{array}$} & $\begin{array}{l}\text { Responders rate }(50 \% \\
\text { reduction in crying time) }\end{array}$ & $\begin{array}{c}\text { Significantly higher responders rate in the } \\
\text { probiotic group }\end{array}$ \\
\hline & & & & Microbiota composition & $\begin{array}{l}\text { Very high inter-individual variability } \\
\text { Bacteroidetes and genus Bacteroides in } \\
\text { the responders group on day } 21 \text { vs. day } 0\end{array}$ \\
\hline & \multirow{9}{*}{$\begin{array}{l}\text { Sung et al. } \\
2014[42]\end{array}$} & \multirow{9}{*}{$\begin{array}{l}\text { Randomized, double- } \\
\text { blinded, placebo-controlled } \\
\text { study }\end{array}$} & \multirow{6}{*}{$\begin{array}{c}167 \\
F F+B F\end{array}$} & Crying time & $\begin{array}{l}\text { Significantly higher reduction in the } \\
\text { placebo group, especially fussing in } \\
\text { formula-fed infants }\end{array}$ \\
\hline & & & & $\begin{array}{l}\text { Responders rate ( } 50 \% \\
\text { reduction in crying time) }\end{array}$ & No significant differences \\
\hline & & & & Sleep duration of infants & $\begin{array}{l}\text { Significant less sleep in the probiotic group } \\
\qquad(P=0.04)\end{array}$ \\
\hline & & & & Maternal mental health & No significant differences \\
\hline & & & & Family functioning & No significant differences \\
\hline & & & & Parent quality of life & $\begin{array}{l}\text { No significant differences } \\
\text { Significant improvement in both groups at } \\
6 \text { months }\end{array}$ \\
\hline & & & \multirow{2}{*}{65} & Fecal microbiota diversity & No significant differences \\
\hline & & & & Colonization with E. coli & No significant differences \\
\hline & & & 102 & Calprotectin & $\begin{array}{c}\text { No significant differences between groups } \\
\text { Lower levels in the responders group after } \\
1 \text { month }\end{array}$ \\
\hline & \multirow{4}{*}{$\begin{array}{l}\text { Mi et al. } \\
2015[40]\end{array}$} & \multirow{4}{*}{$\begin{array}{l}\text { Observational randomized, } \\
\text { placebo-controlled study }\end{array}$} & \multirow{4}{*}{$\begin{array}{l}42 \\
B F\end{array}$} & Number of responders & $\begin{array}{l}\text { Significantly higher in the probiotic group } \\
\text { ( } 100 \% \text { vs. } 15.7 \% \text { in the placebo group) }\end{array}$ \\
\hline & & & & Crying time & $\begin{array}{l}\text { Significant difference between groups } \\
\text { already at day } 7 \text { (higher after } 4 \text { weeks) }\end{array}$ \\
\hline & & & & Parent satisfaction & $\begin{array}{l}\text { Significantly higher in the probiotic group } \\
\text { since the first week }\end{array}$ \\
\hline & & & & Maternal depression & $\begin{array}{c}\text { Improved significantly in the probiotic } \\
\text { group since the first week }\end{array}$ \\
\hline & \multirow{2}{*}{$\begin{array}{l}\text { Chau et al. } \\
2015[39]\end{array}$} & \multirow{2}{*}{$\begin{array}{c}\text { Randomized, double } \\
\text { blinded, placebo-controlled } \\
\text { study }\end{array}$} & \multirow[t]{2}{*}{$\begin{array}{l}52 \\
\mathrm{BF}\end{array}$} & Crying time & $\begin{array}{c}\text { Significantly shorter in the probiotic group } \\
\text { Significant reduction in the probiotic group } \\
\text { vs. placebo }\end{array}$ \\
\hline & & & & $\begin{array}{l}\text { Responders rate ( } 50 \% \\
\text { reduction in crying time) }\end{array}$ & $\begin{array}{c}\text { Significantly higher in the probiotic group } \\
\text { at day } 21\end{array}$ \\
\hline
\end{tabular}




\begin{tabular}{|c|c|c|c|c|c|}
\hline Probiotic & Study & Design & Population & Endpoints & Results \\
\hline \multirow{6}{*}{$\begin{array}{l}\text { Lactobacillus } \\
\text { rhamnosus GG }\end{array}$} & \multirow{4}{*}{$\begin{array}{l}\text { Pärtty et } \\
\text { al. } 2015 \\
\text { [45] }\end{array}$} & \multirow{4}{*}{$\begin{array}{c}\text { Randomized, double- } \\
\text { blinded, placebo controlled } \\
\text { study }\end{array}$} & \multirow{4}{*}{$\begin{array}{c}30 \\
F F+B F\end{array}$} & Daily crying (crying diary) & No differences at the end of the study \\
\hline & & & & $\begin{array}{l}\text { Parents subjective report } \\
\text { of daily crying }\end{array}$ & $\begin{array}{l}\text { Lower number of crying days in the } \\
\text { probiotic group and higher rate of } \\
\text { responders }\end{array}$ \\
\hline & & & & Fecal calprotectin & No significant change \\
\hline & & & & Microbiota changes & $\begin{array}{l}\text { No statistical differences in microbiota } \\
\text { composition } \\
\text { Significant increase in different } \\
\text { Bifidobacterium species }\end{array}$ \\
\hline & \multirow{2}{*}{$\begin{array}{c}\text { Fatheree } \\
\text { et al. } 2016 \\
{[46]}\end{array}$} & \multirow{2}{*}{$\begin{array}{l}\text { Randomized, double- } \\
\text { blinded, placebo-controlled } \\
\text { pilot study (LGG+ formula) }\end{array}$} & \multirow[b]{2}{*}{$\begin{array}{l}20 \\
\mathrm{FF}\end{array}$} & Crying time & No differences \\
\hline & & & & Microbiota changes & $\begin{array}{l}\text { No differences in diversity (erratic } \\
\text { evolution) } \\
\text { No differences at the genus level } \\
\text { Significant increase in L. rhamnosus }\end{array}$ \\
\hline $\begin{array}{l}\text { Bifidobacterium } \\
\text { breve } \mathrm{BR} 03+B \\
\quad \text { breve } \mathrm{B} 632\end{array}$ & $\begin{array}{c}\text { Giglione } \\
\text { et al. } 2016 \\
{[47]}\end{array}$ & $\begin{array}{l}\text { Randomized, double- } \\
\text { blinded, placebo-controlled } \\
\text { study. Prophylactic } \\
\text { intervention }\end{array}$ & $\begin{array}{c}60 \\
F F+B F\end{array}$ & Reduction in crying time & $\begin{array}{l}\text { No significant effects in the full population } \\
\text { of the study } \\
\text { Significant reduction of crying time vs. } \\
\text { placebo in the formula-fed group only, } \\
\text { after } 3 \text { months of treatment }\end{array}$ \\
\hline \multirow{2}{*}{$\begin{array}{l}\text { Pediococcus } \\
\text { pentosaceus } \\
\text { CECT } 8330+ \\
\text { Bifidobacterium } \\
\text { longum CECT } 7894\end{array}$} & $\begin{array}{l}\text { Santas et } \\
\text { al. } 2015 \\
{[49]}\end{array}$ & $\begin{array}{l}\text { Randomized, double- } \\
\text { blinded, placebo-controlled } \\
\text { pilot study }\end{array}$ & $\begin{array}{c}20 \\
F F+B F\end{array}$ & Crying time & $\begin{array}{c}\text { Trend towards greater reduction in crying } \\
\text { time in the probiotic group compared to } \\
\text { placebo, after } 14 \text { days }\end{array}$ \\
\hline & $\begin{array}{l}\text { Tintore et } \\
\text { al. } 2017 \\
{[50]}\end{array}$ & $\begin{array}{l}\text { Randomized, double-blind } \\
\text { placebo-controlled pilot } \\
\text { study }\end{array}$ & $\begin{array}{c}10 \\
F F+B F\end{array}$ & Microbiota diversity & $\begin{array}{l}\text { Increase in overall microbiota diversity in } \\
\text { probiotic (inversely correlated to crying } \\
\text { time in the overall study population) }\end{array}$ \\
\hline \multirow{4}{*}{$\begin{array}{c}\text { Lactobacillus casei, L. } \\
\text { rhamnosus, } \\
\text { L. bulgaricus, } \\
\text { L. acidophilus, } \\
\text { Streptococcus } \\
\text { thermophilus, } \\
\text { Bifidobacterium } \\
\text { breve, } \text { B. infantis } \\
\text { and } \\
\text { fructooligosacharides }\end{array}$} & \multirow{4}{*}{\begin{tabular}{|} 
Kianifar et \\
al. 2014 \\
[51] \\
\end{tabular}} & \multirow{4}{*}{$\begin{array}{c}\text { Randomized, double- } \\
\text { blinded, placebo controlled } \\
\text { study }\end{array}$} & \multirow{4}{*}{$\begin{array}{l}45 \\
B F\end{array}$} & $\begin{array}{l}\text { Responders rate ( } 50 \% \\
\text { reduction in crying time) }\end{array}$ & $\begin{array}{l}\text { Significantly higher in the probiotic group } \\
\text { at days } 7 \text { and } 30\end{array}$ \\
\hline & & & & Crying time & $\begin{array}{l}\text { Significant reduction in the probiotic group } \\
\text { at days } 7 \text { and } 30\end{array}$ \\
\hline & & & & Symptom resolution & $\begin{array}{l}\text { Significantly higher in the probiotic group } \\
\text { at day } 7 \text {, loss of significance at day } 30\end{array}$ \\
\hline & & & & Weight gain & $\begin{array}{l}\text { No significant changes at the end of the } \\
\text { intervention }\end{array}$ \\
\hline
\end{tabular}

including 180 healthy infants aged 3-24 months, prophylactic administration of a standard milk-based formula containing a strain of Bifidobacterium lactis BB-12 and an unspecified strain of Streptococcus thermophilus resulted in a reduction of the incidence of colic, compared to controls [36]. The study represented one of the firsts proofs of the important role of Bifidobacteria as potential probiotics for preventing infant colic, but to our knowledge, no therapeutic studies have assessed the effectiveness of this combination as a treatment of infant colic after the onset of the inconsolable crying behavior.

Subsequently, Lactobacillus reuteri DSM 17938 has been one of the most studied probiotic strains for treating infant colic. Several small studies in predominantly breast-fed colicky infants have consistently reported a significant effect on infant colic vs. controls [37-40] and, according to meta-analysis, the effects were most evident after 21 days of supplementation [41]. However, a randomized study on a larger population including both breastfed and formula-fed colicky infants reported conflicting results, due to a lack of significant difference in responder rate in the overall population $(P=0.23)$, and a significant increase in crying and especially fussing in the subgroup of formula-fed infants (79 minutes on average, $\mathrm{P}=0.005)[42,43]$. Following these studies, 
the latest World Gastroenterology Organization guidelines on probiotics indicate that $L$. reuteri DSM 17938 may be effective for breastfed infants with colic, but at this stage, the probiotic cannot be recommended for treating infantile colic in formulafed infants, nor can be routinely used to prevent infantile colic [43].

The well-known probiotic strain Lactobacillus rhamnosus GG, while being strongly supported for the treatment of acute diarrhea in children [44], has not reached positive results for the treatment of baby colic in clinical trials. In a first study, diaryverified crying time did not reach a statistical difference upon L. rhamnosus GG supplementation, despite parental subjective assessment of crying suggesting some effectiveness [45]. Of note, this study replicated the finding that Bifidobacteria relative abundance was higher in healthy controls than in colicky infants. A more recent study also reported a lack of efficacy of LGGsupplemented formula with respect to the control one, and little impact on the microbiota composition and on inflammation was observed [46]. These results add to the growing evidence that probiotic effects are strain-specific and condition-specific, as suggested by WGO guidelines [43].

More recently, a combination of Bifidobacteria - B. breve BR03 and $B$. breve $B 632$ - has shown a significant reduction in crying time in a subgroup of formula-fed infants after 3 months of prophylactic treatment [47]. However, no significant differences were observed for the full population including breastfed infants. As observed in the study with B. lactis BB-12 and S. termophilus [36], these results suggest Bifidobacteria may be useful for infantile colic and support the preventive use of the specific strains studied against infant colic in formula-fed infants, but are not sufficient to confirm their effectiveness as a treatment for colicky babies.

Pediococci are round-shaped bacteria belonging to the Lactobacillus group [48]. A probiotic formula including strains Pediococcus pentosaceus CECT 8330 and Bifidobacterium longum CECT 7894 showed a significant trend towards a greater reduction in daily crying time in just 14 days, in a pilot RCT comparing to placebo $(p=0.083)$. The study included both breastfed and formula-fed colicky infants, and in vitro data suggest that the mechanism of action for the probiotic formula may be ascribed to an antagonistic effect against Enterobacteria and a capacity to counteract the pro-inflammatory effect of their endotoxin

\section{References}

1 Koppen IJN, Nurko S, Saps M, Lorenzo C Di, Marc A (2017) The pediatric Rome IV criteria: what's new? Expert Rev Gastroenterol Hepatol 0: 1-9.

2 Camilleri M, Park SY, Scarpato E, Staiano A (2017) Exploring hypotheses and rationale for causes of infantile colic. Neurogastroenterol Motil 29: 1-11.

3 Vandenplas Y, Abkari A, Bellaiche M, Benninga M, Chouraqui JP (2015) Prevalence and Health Outcomes of Functional Gastrointestinal Symptoms in Infants From Birth to 12 Months of Age. J Pediatr Gastroenterol Nutr 61: 531-537. on the immune cells [49]. Clinical studies with larger sample sizes are required to validate these findings. However, findings are further supported by an additional study on the observed changes in the microbiome after the supplementation with said probiotic strains compared to placebo [50]. More precisely, this study reports an increase in $\alpha$-diversity in the probiotic group, which correlated with a reduction in the total crying time in the full study population. Also, an increase in Bifidobacterium and a decrease in species belonging to the Enterobacteriaceae family was observed in probiotic-treated infants compared to placebotreated ones. Noteworthy, these results are in agreement with the in vitro studies on the antagonistic effects of the probiotic strains used [49], as well as with observational evidence on the relationship between infant colic and microbiome diversity, Enterobacterial abundance and Bifidobacterial abundance $[12,19]$.

Finally, symbiotic formulas have also been assessed in the management of infant colic, showing promising results. A mixture of fructooligosaccharides (FOS) and seven unspecified probiotic strains of the species Lactobacillus casei, L. rhamnosus, L. bulgaricus, Streptococcus thermophilus, Bifidobacterium breve, and $B$. infantis significantly improved symptoms in colicky babies in comparison to placebo [51,52]. Positive effects where observed already on day 7; however, the positive effect of the probiotic vs. placebo had disappeared after 30 days of treatment. In addition, the fact that the probiotic strains were not specified hinders the subsequent replication of this study.

\section{Conclusions}

Effective management of infant colic, a condition that severely impacts family quality of life, represents an unmet medical need. Specific changes in gut microbiome have been described in colicky babies, affecting overall diversity and relative abundance of specific bacterial groups such as Enterobacteria, Bifidobacteria and Lactobacilli. In this regard, several clinical trials report evidence of the usefulness of some probiotics to treat this condition. Importantly, not all probiotics studied appear to be effective, and some seem to depend on the infant's feeding (breastfed vs. formula-fed) for their effectiveness. Further evidence about validated mechanisms of action and randomized clinical studies with larger sample sizes are needed to confirm the benefits of this approach.

4 Lucassen PL, Assendelft WJ, van Eijk JT, Gubbels JW, Douwesa C, et al. (2001) Systematic review of the occurrence of infantile colic in the community. Arch Dis Child 84: 398-403.

5 Wessel MA, Cobb JC, Jackson EB, Harris GS, Detwiler AC (1954) Paroxysmal fussing in infancy, sometimes called colic. Pediatrics 14 : 421-435.

6 Benninga MA, Nurko S, Faure C, Hyman PE, Schechter NL (2016) Childhood functional gastrointestinal disorders: Neonate/toddler Gastroenterology 150: 1443-1455.

7 Kheir AEM (2012) Infantile colic, facts and fiction. Ital J Pediatr 38: 34.

8 lacovou M, Ralston R, Muir J, Walker K, Truby H (2012) Dietary 
Management of Infantile Colic: A Systematic Review. Matern Child Heal J 16: 1319-1331.

9 Li R, Fein SB, Chen J, Grummer-Strawn LM (2008) Why mothers stop breastfeeding: mothers' self-reported reasons for stopping during the first year. Pediatrics 122 suppl: S69-S76.

10 Kaley F, Reid V, Flynn E (2011) The psychology of infant colic: A review of current research. Infant Ment Health J 32: 526-541.

11 de Weerth C, Fuentes S, de Vos WM (2013) Crying in infants: on the possible role of intestinal microbiota in the development of colic. Gut Microbes 4: 416-421.

12 de Weerth C, Fuentes S, Puylaert P, de Vos WM (2013) Intestinal microbiota of infants with colic: development and specific signatures. Pediatrics 131: e550-558.

13 Dubois NE, Gregory KE (2016) Characterizing the Intestinal Microbiome in Infantile Colic: Findings Based on an Integrative Review of the Literature. Biol Res Nurs 18: 307-315.

14 Savino F, Cresi F, Pautasso S, Palumeri E, Tullio V, et al. (2004) Intestinal microflora in breastfed colicky and non-colicky infants. Acta Paediatr 93: 825-829.

15 Savino F, Bailo E, Oggero R, Tullio V, Roana J, et al. (2005) Bacterial counts of intestinal Lactobacillus species in infants with colic. Pediatr Allergy Immunol 16: 72-75.

16 Verduci E, Arrizza C, Riva E, Giovannini M (2013) Microbiota and infantile colic: What's new? Int J Probiotics Prebiotics 8: 25-28.

17 Savino F, Cordisco L, Tarasco V, Calabrese R, Palumeri E, et al. (2009) Molecular identification of coliform bacteria from colicky breastfed infants. Acta Paediatr Int J Paediatr 98: 1582-1588.

18 de Weerth C, Fuentes S, Puylaert P, de Vos WM (2013) Intestinal Microbiota of Infants With Colic: Development and Specific Signatures. Pediatrics 131: e550-558.

19 Rhoads JM, Fatheree NY, Norori J, Liu Y, Lucke JF, et al. (2009) Altered fecal microflora and increased fecal calprotectin in infants with colic. J Pediatr 155: 823-828.

20 Pärtty A, Kalliomäki M, Endo A, Salminen S, Isolauri E (2012) Compositional development of Bifidobacterium and Lactobacillus microbiota is linked with crying and fussing in early infancy. PLoS One 7: 1-5.

21 Roos S, Dicksved J, Tarasco V, Locatelli E, Ricceri F, et al. (2013) 454 Pyrosequencing Analysis on Faecal Samples from a Randomized DBPC Trial of Colicky Infants Treated with Lactobacillus reuteri DSM 17938. PLoS One 8: e56710.

22 Hatakka K, Savilahti E, Pönkä A, Meurman JH, Poussa T, et al. (2001) Effect of long term consumption of probiotic milk on infections in children attending day care centres: double blind, randomised trial. BMJ 322: 1327.

23 Lehtonen L, Korvenranta H, Eerola E (1994) Intestinal microflora in colicky and noncolicky infants : bacterial cultures and gas-liquid chromatography. J Pediatr Gastroenterol Nutr 19: 310-314.

24 Wikoff WR, Anfora AT, Liu J, Schultz PG, Lesley SA, et al. (2009) Metabolomics analysis reveals large effects of gut microflora on mammalian blood metabolites. Proc Natl Acad Sci 106: 3698-3703.

25 Konishi H, Fujiya M, Kohgo Y (2013) Traffic control of bacteria-derived molecules: A new system of host-bacterial crosstalk. Int J Cell Biol 20: 757-768.

26 Gupta SK (2002) Is colic a gastrointestinal disorder? Curr Opin Pediatr 14: $588-592$.
27 Ács N, Bagi Z, Rákhely G, Minárovics J, Nagy K, Kovács KL, et al. (2015) Bioaugmentation of biogas production by a hydrogen-producing bacterium. Bio resour Technol 186: 286-293.

28 Lindberg AA, Weintraub A, Zähringer U, Rietschel ET (1990) Structureactivity relationships in Lipopolysaccharides of bacteroides fragilis. Rev Infect Dis 12: S133-S141.

29 Benson S, Kattoor J, Wegner A, Hammes F, Reidick D, et al. (2012) Acute experimental endotoxemia induces visceral hypersensitivity and altered pain evaluation in healthy humans. Pain 153: 794-799.

30 Moriez R, Salvador-Cartier C, Theodorou V, Fioramonti J, Eutamene $\mathrm{H}$ (2005) Myosin light chain kinase is involved in lipopolysaccharideinduced disruption of colonic epithelial barrier and bacterial translocation in rats. Am J Pathol 167: 1071-1079.

31 Wegner A, Elsenbruch S, Rebernik L, Roderigo T, Engelbrecht E, et al (2015) Inflammation-induced pain sensitization in men and women. Pain 156: 1954-1964

32 Baarlen PV, Troost FJ, Hemert SV, Meer C, Vos WM, et al. (2008) Differential NF- B pathways induction by Lactobacillus plantarum in the duodenum of healthy. Proc Natl Acad Sci 106: 2371-2376.

33 Verdu EF (2009) Probiotics effects on gastrointestinal function: Beyond the gut? Neurogastroenterol Motil 21: 477-480.

34 Chichlowski M, Rudolph C (2015) Visceral pain and gastrointestinal microbiome. J Neurogastroenterol Motil 21: 172-181.

35 Wadher K, Mahore J, Umekar J (2010) Probiotics: living medicines in health maintenance and disease prevention. Int J Pharma Bio Sci 1: 1-9.

36 Saavedra JM, Abi-Hanna A, Moore N, Yolken RH (2004) Long-term consumption of infant formulas containing live probiotic bacteria: Tolerance and safety. Am J Clin Nutr 79: 261-267.

37 Savino F, Cordisco L, Tarasco V, Palumeri E, Calabrese R, et al. (2010) Lactobacillus reuteri DSM 17938 in infantile colic: a randomized, double-blind, placebo-controlled trial. Pediatrics 126: e526-e533.

38 Szajewska H, Gyrczuk E, Horvath A (2013) Lactobacillus reuteri DSM 17938 for the management of infantile colic in breastfed infants: A randomized, double-blind, placebo-controlled trial. J Pediatr 162: 257-262.

39 Chau K, Lau E, Greenberg S, Jacobson S, Yazdani-Brojeni P, et al. (2015) Probiotics for infantile colic: a randomized, double-blind, placebo-controlled trial investigating Lactobacillus reuteri DSM 17938. J Pediatr 166: 74-78.

40 Mi GL, Zhao L, Qiao DD, Kang WQ, Tang MQ, Xu JK (2015) Effectiveness of Lactobacillus reuteri in infantile colic and colicky induced maternal depression: a prospective single blind randomized trial. Antonie van Leeuwenhoek, Int J Gen Mol Microbiol 107: 1547-1553.

41 Monfrin U (2014) The efficacy of Lactobacillus reuteri DSM 17938 in infants and children: a review of the current evidence. Eur J Pediatr 173: 1327-1337.

42 Sung V, Hiscock H, Tang MLK, Mensah FK, Nation ML, et al. (2014) Treating infant colic with the probiotic Lactobacillus reuteri: double blind, placebo controlled randomised trial. Bmj 348: g2107.

43 Guarner F, Sanders ME, Eliakim R, Fedorak R, Gangl A, et al. (2017) WGO Global Guideline: Probiotics and prebiotics 33 .

44 Szajewska H, Guarino A, Hojsak I, Indrio F, Kolacek S, et al. (2014) Use of probiotics for management of acute gastroenteritis: a position paper by the ESPGHAN Working Group for Probiotics and Prebiotics. J Pediatr Gastroenterol Nutr 58: 531-539. 
45 Pärtty A, Lehtonen L, Kalliomäki M, Salminen S, Isolauri E (2015) Probiotic Lactobacillus rhamnosus GG therapy and microbiological programming in infantile colic: a randomized, controlled trial. Pediatr Res 78: 470-475.

46 Fatheree NY (2016) Hypoallergenic formula with Lactobacillus rhamnosus GG for babies with colic: A pilot study of recruitment, retention, and fecal biomarkers. World J Gastrointest Pathophysiol 7: 160 .

47 Giglione E, Prodam F, Bellone S, Monticone S, Beux S, et al. (2016) The Association of Bifidobacterium breve BR03 and B632 is Effective to Prevent Colics in Bottle-fed Infants. J Clin Gastroenterol 50: S164-S167.

48 Zheng J, Ruan L, Sun M, Gänzle M (2015) A genomic view of lactobacilli and pediococci demonstrates that phylogeny matches ecology and physiology. Appl Environ Microbiol 81: 7233-7243.
49 Santas J, Fuentes MC, Tormo R, Guayta-Escolies R, Lázaro E (2015) Pediococcus pentosaceus CECT 8330 and bifidobacterium longum CECT 7894 show a trend towards lowering infantile excessive crying syndrome in a pilot clinical trial. Int J Pharma Bio Sci 6: 458-466.

50 Tintoré M, Cuné J (2017) Probiotic treatment with AB-Kolicare ${ }^{\circledR}$ causes changes in the microbiota which correlate with a reduction in crying time. Int J Pharma Bio Sci 8: 281-288.

51 Kianifar H, Ahanchian H, Grover Z, Jafari S, Noorbakhsh Z, et al. (2014) Synbiotic in the management of infantile colic: A randomised controlled trial. J Paediatr Child Health 50: 801-805.

52 Pärtty A, Kalliomäki M, Endo A, Salminen S, Isolauri E (2012) Compositional development of Bifidobacterium and Lactobacillus microbiota is linked with crying and fussing in early infancy. PLoS One 7: 1-5. 